\title{
Assessment of anthropogenic activity impact on the oil-field exploitations near Moinesti city, Bacau County, Romania
}

\section{LAURA RUSAI (FERENT⿻) ${ }^{1 *}$, IULIANA LAZAR ${ }^{1}$, MARIA-EMA FACIU ${ }^{2}$, AZLAN KAMARI ${ }^{3}$}

${ }^{1}$ Vasile Alecsandri University of Bacau, Department of Doctoral School, Bacau, Romania ${ }^{2}$ Al. Vlahuta Technological School, Podu Turcului, Bacau, Romania

${ }^{3}$ Universiti Pendidikan Sultan Idris, Perak, Malaysia

\begin{abstract}
Oil-field exploitations that have been done in Moinesti city over the years since 1440 have resulted in soil degradation due to accidents and residual pollution. The location of extraction wells close to the grazing areas has frequently increased questions related to the quality of soil and vegetation for these areas. The aim of the study was to assess the degree of pollution considering total petroleum hydrocarbons and heavy metals in soil and spontaneous vegetation from one of the grazing areas located under the influence of oil pipe transport and oil wells. 35 locations were considered for soil and vegetation sampling and the measured data were mapped and analysed using spatial distribution correlations. The results indicated that, the heavy metal and TPH concentrations in the investigated soils exceeded the thresholds values. They also indicated the existence of residual pollution in the investigated soils. Often, $\mathrm{Cd}$ and $\mathrm{Pb}$ determined concentrations exceeded the normal values for the spontaneous flora, thus it can be concluded that a heavy metal contamination may be manifested at the plant level. The investigated area can be estimated as being a risk zone demanding involvement for depollution.
\end{abstract}

Keywords Pollution, total petroleum hydrocarbons, heavy metals.

To cite this article: RUSAI (FERENT,) L, LAZAR I, FACIU M-A, KAMARI A. Assessment of anthropogenic activity impact on the oil-field exploitations near Moinesti city, Bacau County, Romania. Rom Biotechnol Lett. 2020; 25(1): 1143-1150. DOI: $10.25083 / \mathrm{rbl} / 25.1 / 1143.1150$ 


\section{Introduction}

Moinesti has an important place among the oil-field exploitation regions in our country. A feature of the Moinesti area is that most wells and pipelines transporting oil products are in the immediate vicinity of residential areas or grazing areas.

Because of the prolonged activity of the oil extraction industry in this area and considering its use by locals pasture, an analysis was required in relation to the concentrations of total petroleum hydrocarbons and heavy metals in the soil sampled in the study area, and to the degree of bioaccumulation of pollutants in the spontaneous flora species.

Spilt oil changes the physical, chemical and biological properties of the soil, affects flora and fauna endangering the safety of ecosystems and the health of the population because of the circulation of pollutants through trophic chains (DA MUSTAFA \& al [1]; AM MICHAEL \& al [2]; L PÂRVAN \& al [3]). Soil $\mathrm{pH}$ reduction also favours the availability of heavy metals for the plants that absorb them during the growth process and produces a toxic effect on them (BM MCBRIDE [4]). Also, the presence of total petroleum hydrocarbons in soil promotes the availability of heavy metals for plants.

Excessive soil concentrations of heavy metals and total petroleum hydrocarbons have been reported in oilaffected areas (IO ASIA \& al [5]; JG LÜ \& al [6]). The contamination with heavy metals has a serious impact on biodiversity and it may have devastating effects, including cancers (SJ ROBERTSON \& al [7]; A SINGH \& al [8]).

The article presents the results obtained from the analysis of soil samples from the investigated area on the concentrations of total petroleum hydrocarbons (TPH), heavy metals $(\mathrm{Cd}, \mathrm{Cu}, \mathrm{Mn}, \mathrm{Pb}, \mathrm{Ni}, \mathrm{Zn})$ and $\mathrm{pH}$ values. Heavy metals $(\mathrm{Cd}, \mathrm{Cu}, \mathrm{Pb})$ were analysed for the spontaneous flora species because the presence of petroleum hydrocarbons in the soil favours the absorption of heavy metals by plants.

In addition to statistics, spatial distribution analysis was used in order to highlight and confirm pollution sources and migration of pollutants.

\section{Materials and Methods}

Measurements were carried out in the contact area between the Sub-Carpathians of Moldova and Eastern Carpathians, within the administrative territory of Moinesti, Bacau County, on the northern slope of the Osoiu Hill.

35 sampling points were established as following:

- 30 points (P1-P30) in a pasture area where no extraction well is currently available. The area is located on one of the slopes of the hill, with an industrial road and a transport pipeline positioned on the top. A part of the area found $10 \mathrm{~m}$ away from the transport pipe and following the relief to the base of the slope was vegetation free and showed oil traces. The soil type was modified, being mainly sandy. The sampling locations covered the identified area, as well as its close proximity to its left and right sides, and also other remote locations where no environmental changes were noticed;

- 4 points around an extraction well (PS1-PS4). The extraction well is located on an opposite slope of the hill, thus, any ecological accidents caused by it, cannot influence the area;

- control location. The position of the control location was chosen at approximately $1 \mathrm{~km}$ from the investigated area, on another hilltop where no extraction wells or transport pipelines are currently in place.

Soil sampling was carried out according to STAS 7184/1-75 (ASRO [9]) with a 30-cm Edelman auger. Each location had a $2 \times 2 \mathrm{~m}$ perimeter of which five soil samples were taken (from the 4 corners and from the centre) from the depths of $0-30 \mathrm{~cm}$ and $30-60 \mathrm{~cm}$.

The storage and preparation of soil samples for chemical analyses were carried out according to ISO 11464/1994 (ISO [10]).

Samples of plant material were taken from the same points from which the soil samples were collected, according to the international standards SI 950 and SI 1839 (ASRO [11, 12]).

The methodology used to identify soil total petroleum hydrocarbons (TPH) was centred on the infrared absorption spectroscopy and on the chemometric analysis. The method uses statistical computing techniques, it is fast and non-invasive, and it is suitable for measuring high concentrations of soil pollutants up to $250 \mathrm{~g} / \mathrm{Kg} \mathrm{TPH}$. The method was described in detail in another article which is currently under evaluation.

$\mathrm{pH}$ measurements were performed according to the standard ISO 10390/2005 (ISO [13]) with the help of WTW InoLAB equipment (WTW [14]). The obtained values were reported to the ones from the standard.

To measure the heavy metal concentration, dry soil and plant material samples were first subjected to a digestion process. The digestion of the organic component was performed according to the soils characterization protocol of De Vigo University in Spain (LABORATORIO GRUPO DE BIOPROCESOS [15]). The plant material was digested by using an aqua regia mixture in a molar ratio of 3:1 $\mathrm{HCl}: \mathrm{HNO}_{3}$ according to US EPA 3051A.

To measure the soil concentrations of heavy metals the Varian atomic absorption spectrophotometer was used according to the standard ISO 11047/1998 (ISO [16]) and to the user manual (VARIAN [17]).

The values obtained for soil samples were reported at the reference values for the heavy metals concentrations in soil established according to the Order of the Minister no.756/1997 (GOVERNMENT [18]). The Table 1 shows the thresholds for the heavy metals analysed in this study.

The measured values for the vegetal samples were compared to the maximum allowed limits according to the Order of the Minister no. 640/19.09.2001 (GOVERNMENT [19]) according to the Table 2. 
Table 1. Threshold values for heavy metals in $\mathrm{mg} / \mathrm{Kg}$ dry soil (NV - normal value, AT - alert threshold, IT - intervention threshold) for soil with sensitive use according to OM 756/1997

\begin{tabular}{|c|c|c|c|}
\hline \hline Elements & NV $(\mathrm{mg} / \mathrm{Kg}$ dry soils $)$ & $\mathbf{A T}(\mathrm{mg} / \mathrm{Kg}$ dry soils $)$ & IT $(\mathrm{mg} / \mathrm{Kg}$ dry soils $)$ \\
\hline \hline $\mathbf{N i}$ & 20 & 75 & 150 \\
$\mathbf{Z n}$ & 100 & 300 & 600 \\
$\mathbf{M n}$ & 900 & 1500 & 2500 \\
$\mathbf{C d}$ & 1 & 3 & 5 \\
$\mathbf{C u}$ & 20 & 100 & 200 \\
$\mathbf{P b}$ & 20 & 50 & 100 \\
\hline \hline
\end{tabular}

Table 2. Allowed maximum limits for heavy metals that are analysed in fresh vegetables and fruits (in $\mathrm{mg} / \mathrm{Kg}$ dried plant)

\begin{tabular}{|l|c|c|c|c|c|c|c|}
\hline Vegetables and fruits & As & $\mathbf{C d}$ & $\mathbf{P b}$ & $\mathbf{Z n}$ & $\mathbf{C u}$ & $\mathbf{S n}$ & $\mathbf{H g}$ \\
\hline Fresh vegetables, except for leaf vegetables & 0.5 & 0.1 & 0.5 & 15 & 5.0 & - & 0.05 \\
\hline Leaf vegetables & - & 0.2 & 0.5 & - & - & - & 0.03 \\
\hline Fresh fruits & 0.5 & 0.05 & 0.5 & 5.0 & 5.0 & - & 0.05 \\
\hline
\end{tabular}

The ArcGIS application was used to map the spatial distribution of concentrations by using the Kriging interpolation method (L RUSĂI \& al [20]). The graphical analysis of the data was done using the distribution frequency histogram and the Kolmogorov-Smirnov test (A FIELD [21]). The methodology used to identify soil total petroleum hydrocarbons (TPH) was centred on the infrared absorption spectroscopy. The concentrations of calibration samples were compared with the prediction from the chemometric model.

\section{Results and Discussion}

The values measured for the TPH concentration of the soil at a depth of 0-30 $\mathrm{cm}$ range between $10568.840 \mathrm{mg} / \mathrm{Kg}$ (minimum) and $193140.000 \mathrm{mg} / \mathrm{Kg}$ (maximum), with an average of $49803.040 \mathrm{mg} / \mathrm{Kg}$, the alert threshold has been exceeded in all locations. In comparison to the blank sample taken from the Osoiu Hill, at a depth of 0-30 cm, all the samples recorded higher values than that blank one. According to O.M 756/1997, the blank sample exceeded the intervention threshold $(\mathrm{PI}=500 \mathrm{mg} / \mathrm{Kg}$ ) for both depths. A maximum was recorded on both depths in the identified area that also influences the adjacent sites. Similar results were found by AF POTRA \& al [22] for an area under the influence of an oil product deposit.

The analysis of the distribution map of the TPH concentrations for the $0-30 \mathrm{~cm}$ depth showed an accumulation of high concentrations in the identified area with changes of the soil type and the displacement of the contaminant to the slope base (Fig. 1).

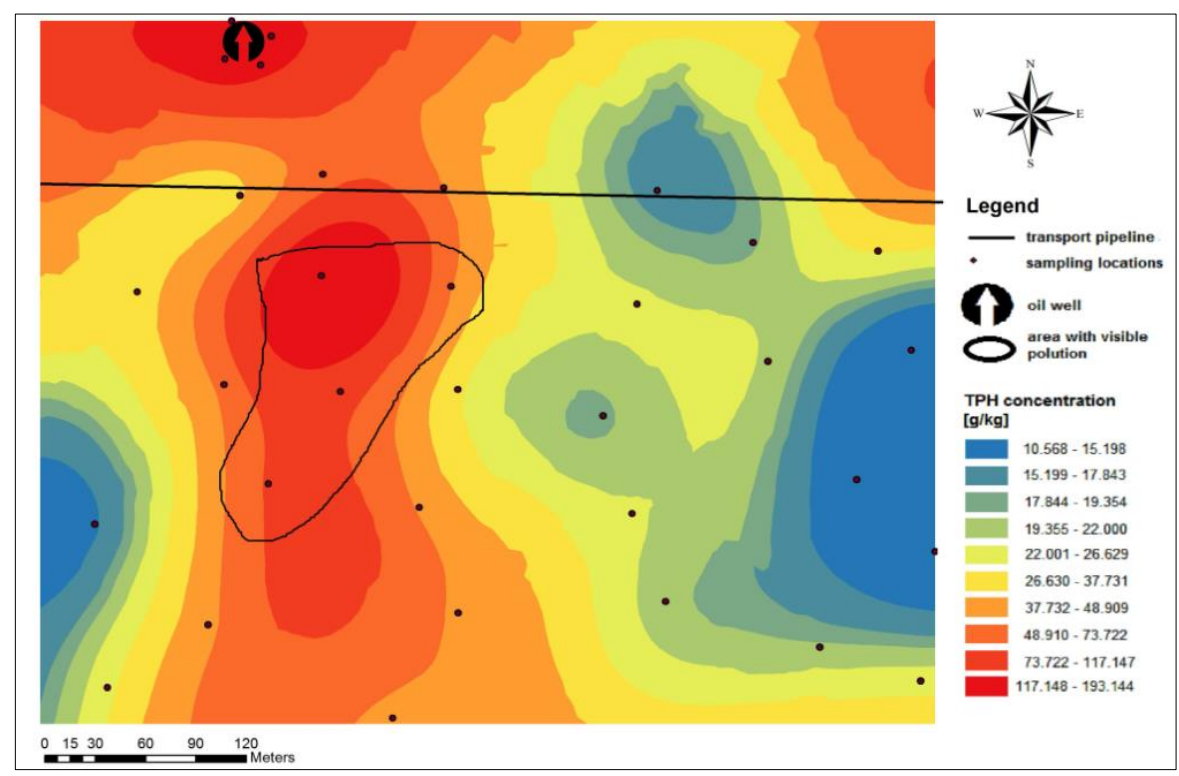

Figure 1. Spatial distribution of soil TPH concentrations at a 0-30 cm depth. The dotted line marks the identified site. 
The measured $\mathrm{pH}$ values for a depth of $0-30 \mathrm{~cm}$ varied between 5.26 (the lowest) and 8.51 (the highest), with an average of 7.24. From the distribution map of the $\mathrm{pH}$ values measured at 0-30 cm depth it could be seen that the acid range values were grouped on the area identified with soil changes, whereas the neutral-alkaline values were spread throughout the studied area (Fig. 2) (L RUSAI \& al [23].

To explain the spatial variation, the values recorded on both depths in the control site were compared, in the four locations associated with the extraction well, in the sites where the acidic range values were found and in the immediate vicinity. It was observed that in the identified area the $\mathrm{pH}$ values were in the acid range for both depths, whereas in the adjacent areas one could observe a difference between values in the depth of $30-60 \mathrm{~cm}$ close to the values in the control location and the values for the soil area that were lower. AF POTRA \& al [22] observed, in an area influenced by an oil product deposit, values of $\mathrm{pH}$ varying in the acidic to normal range for both the top soil, and the deep layer, but higher for the second.

Considering the correlation between the distribution maps for TPH and $\mathrm{pH}$, it can be concluded that an environmental accident occurred in the identified area which changed the soil properties (DA MUSTAFA \& al [1]; AM MICHAEL \& al [2]; L PÂRVAN \& al [3]).

IM BERAR \& al [24] analysed soils polluted with heavy metals and measured $\mathrm{pH}$ values varying from strongly acid to moderate acid.

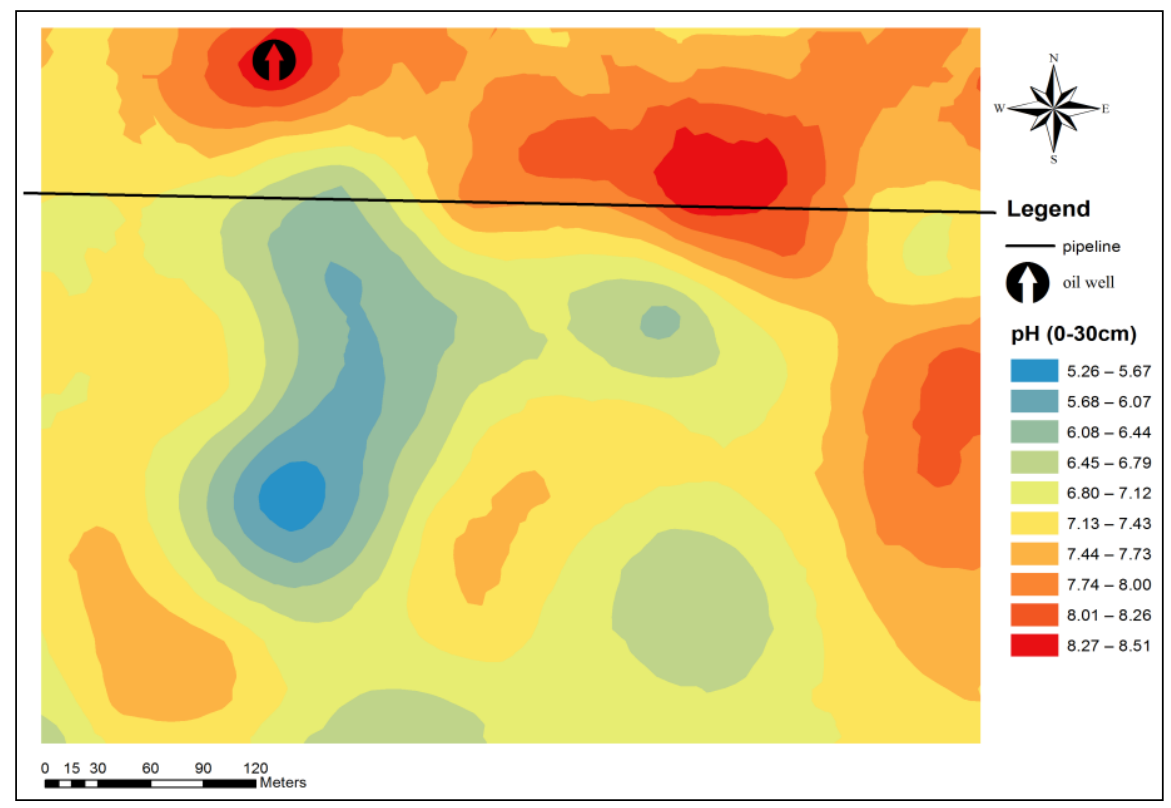

Figure 1. Spatial distribution of recorded values for soil $\mathrm{pH}$ for a $0-30 \mathrm{~cm}$ depth.

The dotted line marks the identified site.

Six heavy metals $(\mathrm{Cd}, \mathrm{Cu}, \mathrm{Mn}, \mathrm{Pb}, \mathrm{Ni}, \mathrm{Zn})$ were analysed during the study, and the strongest exceeding of the thresholds (GOVERNMENT [18]) were observed for $\mathrm{Cd}$ and $\mathrm{Pb}$.

The measured values for soil $\mathrm{Cd}$ concentration at a depth of $0-30 \mathrm{~cm}$ varied between $1.200 \mathrm{mg} / \mathrm{Kg}$ dry soil (minimum) and $3.090 \mathrm{mg} / \mathrm{kg}$ dry (maximum) soil with an average of $2.647 \mathrm{mg} / \mathrm{Kg}$ dry soil. In comparison to the blank sample, at a depth of 0-30 cm, lower values than that were recorded for only one sample. Compared to threshold values (GOVERNMENT [18]), all values exceeded the normal value ( $\mathrm{NV}=1 \mathrm{mg} / \mathrm{Kg}$ dry soil), and a number of eight recorded concentrations exceeded the alert threshold (AT=3 $\mathrm{mg} / \mathrm{Kg}$ dry soil), but without exceeding the intervention threshold. All four values corresponding to the locations around the extraction well were close to the alert threshold: $2.90-3.13 \mathrm{mg} / \mathrm{Kg}$. The value of the concentration in the control site $(1.71 \mathrm{mg} / \mathrm{Kg})$ exceeded the normal value according to OM 767/1997 (GOVERNMENT [18]), thus there may be a natural soil load. The analysis of the distribution of values on the two depths showed higher values at the second depth for the control site and 
those near the well, possibly due to the vertical transfer process. For most of the other locations, higher values were recorded at a $0-30 \mathrm{~cm}$ depth.

The values measured for the $\mathrm{Pb}$ concentration of the soil at a depth of 0-30 $\mathrm{cm}$ varied between $20.300 \mathrm{mg} / \mathrm{Kg}$ dry soil (minimum) and $63.410 \mathrm{mg} / \mathrm{Kg}$ dry soil (maximum), with an average of $38.217 \mathrm{mg} / \mathrm{Kg}$ dry soil. The values for 29 sites exceeded the normal value $(\mathrm{NV}=20 \mathrm{mg} / \mathrm{Kg})$, a number of five recorded concentrations exceeded the alert threshold (AT=50 $\mathrm{mg} / \mathrm{Kg}$ ), including two sites close to the extraction well, but without reaching the intervention threshold (IT=100 mg/Kg). The value of the concentration recorded for the blank sample $(25.39 \mathrm{mg} / \mathrm{Kg})$ also exceeded the normal value according to OM 767/1997 (GOVERNMENT [18]).

IO ASIA \& al [5] found in their study concentrations varying between 3.40 and $99.40 \mathrm{mg} / \mathrm{Kg}$ for $\mathrm{Pb}$ and from 0.04 to $0.95 \mathrm{mg} / \mathrm{Kg}$ for $\mathrm{Cd}$. Exceeding of the threshold were registered for all heavy metals analysed except $\mathrm{Ni}$ and $\mathrm{Zn}$. Migration of the heavy metals to the deeper layer were registered also by IM BERAR \& al [23] and CS BĂBUT, \& al [25]. The intervention threshold (GOVERNMENT [18]) was exceeded by 17 times for the top layer and by 28 times for the depth layer in case of $\mathrm{Cd}$ and by 90 times in case of $\mathrm{Pb}$ for the depth layer (CS BĂBUT, \& al [25]).
In our study, the analysis of the distribution of values on the two depths showed higher values at the second depth for most of the locations, the biggest difference being recorded for the sites near the well.

The literature showed a direct relationship between TPH pollution and the presence of high heavy metals concentrations in soil (DA MUSTAFA \& al [1]; IO ASIA $\&$ al [5]). The analysis of the measured values for $\mathrm{Cd}$ and $\mathrm{Pb}$ concentrations in soil led to the following conclusions:

- both heavy metals had a maximum point in the immediate vicinity of the extraction well, which confirmed the conclusions of the literature;

- the analysis of spatial distributions showed a minimum point for both $\mathrm{Cd}$ (Fig. 3) and $\mathrm{Pb}$ (Fig. 4), that didn't show a noticeable pollution of the soil, located in the identified area with soil changes, compared to all the other locations. Correlating this observation with the results obtained from the analysis of TPH concentrations and $\mathrm{pH}$ distribution led to the conclusion of the existence of a new confirmation that an ecological accident was followed by the mechanical decontamination of the affected soil (removing the surface soil and replacing it with one from another source).

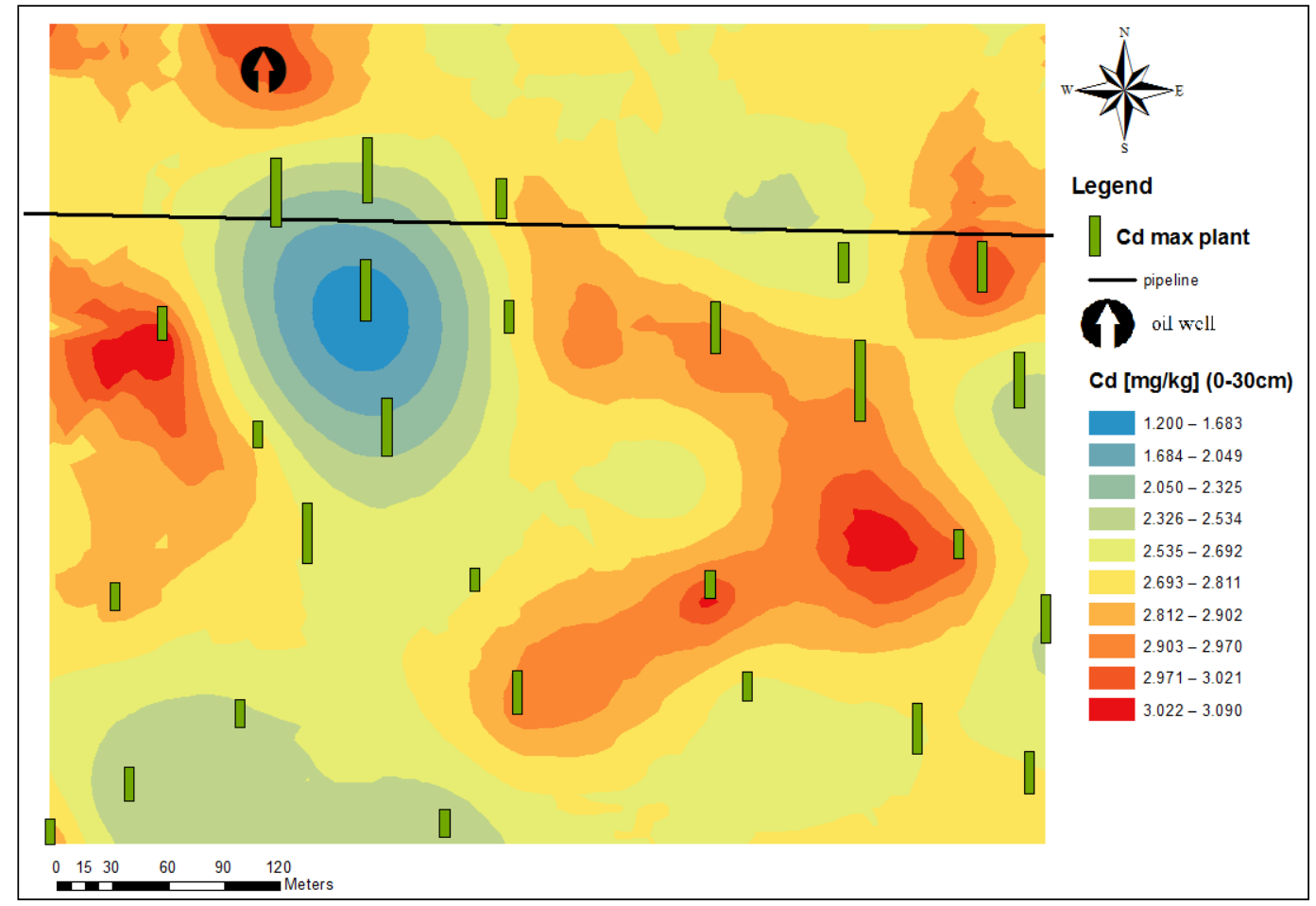

Figure 3. Spatial distribution of the maximum recorded concentrations for the spontaneous flora exceeding the maximum allowed value, overlapped on the soil concentration distribution map for $\mathrm{Cd}$. 


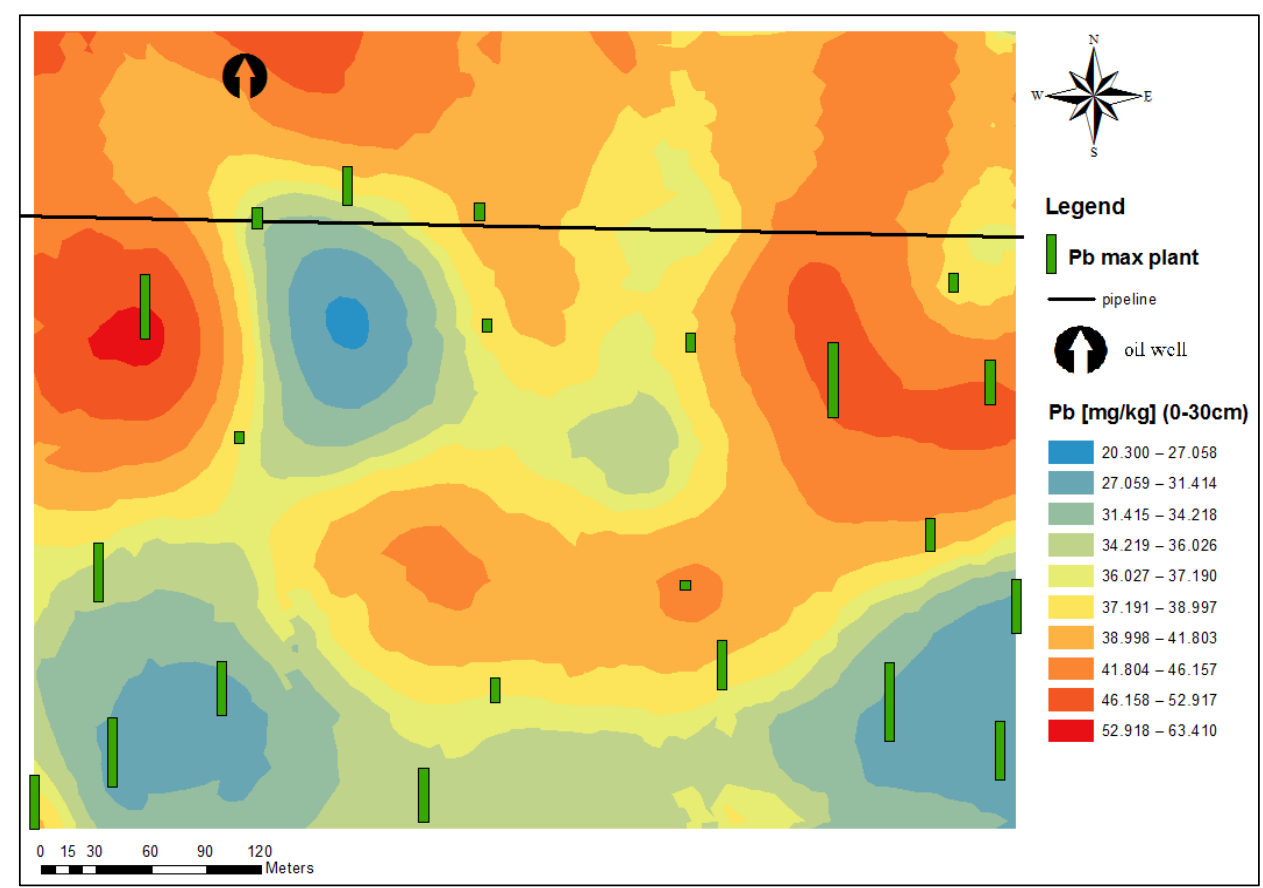

Figure 4. Spatial distribution of the maximum recorded concentrations for the spontaneous flora exceeding the maximum allowed value, overlapped on the soil concentration distribution map for $\mathrm{Pb}$.

$62 \%$ of the plants from the spontaneous flora analysed along the study exceeded the maximum threshold for
Cd concentration (Fig. 5) and $41 \%$ for $\mathrm{Pb}$ concentrations (Fig. 6).

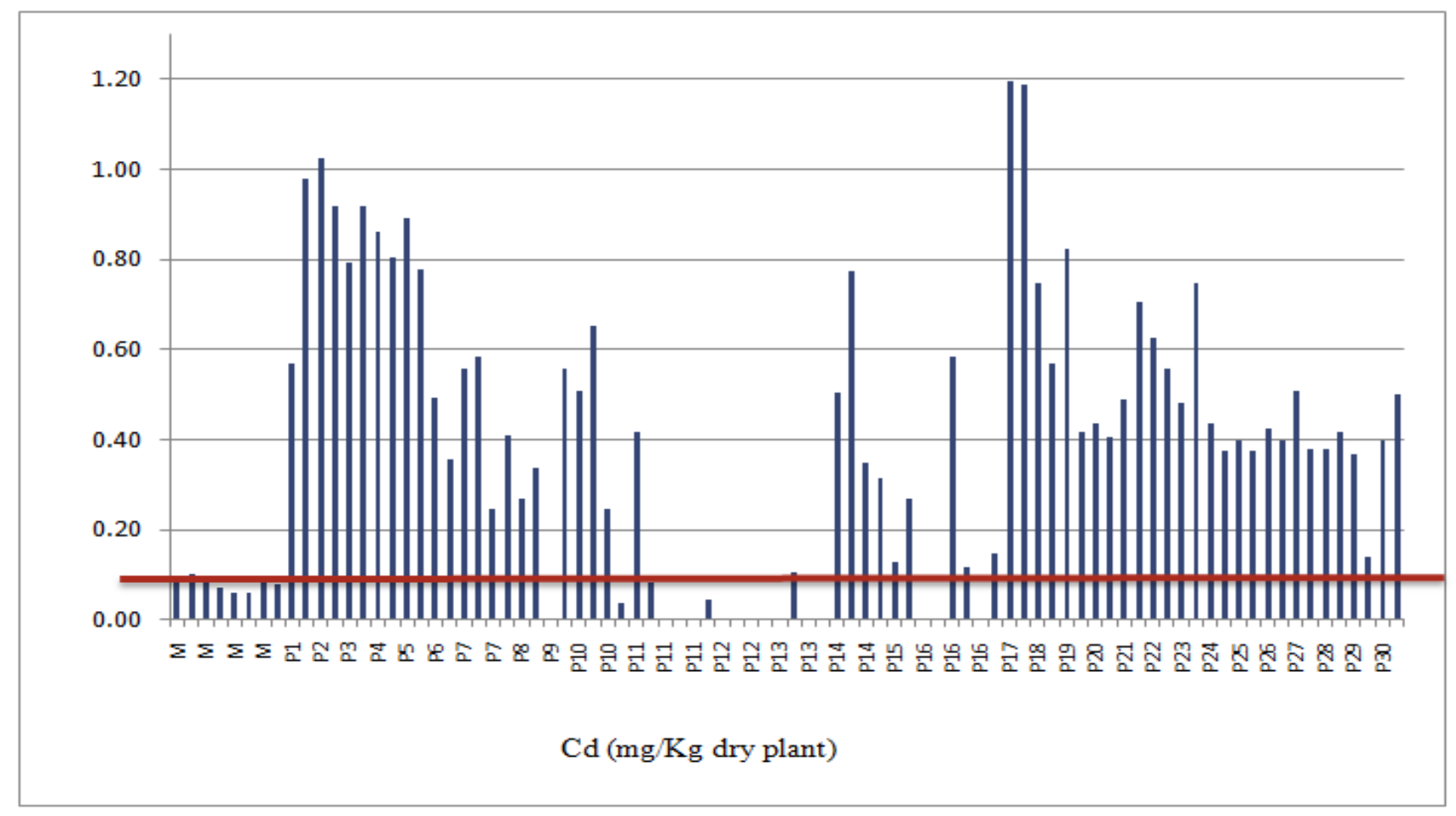

Figure 5. Graphical representation of $\mathrm{Cd}$ concentrations recorded for the studied plants. 


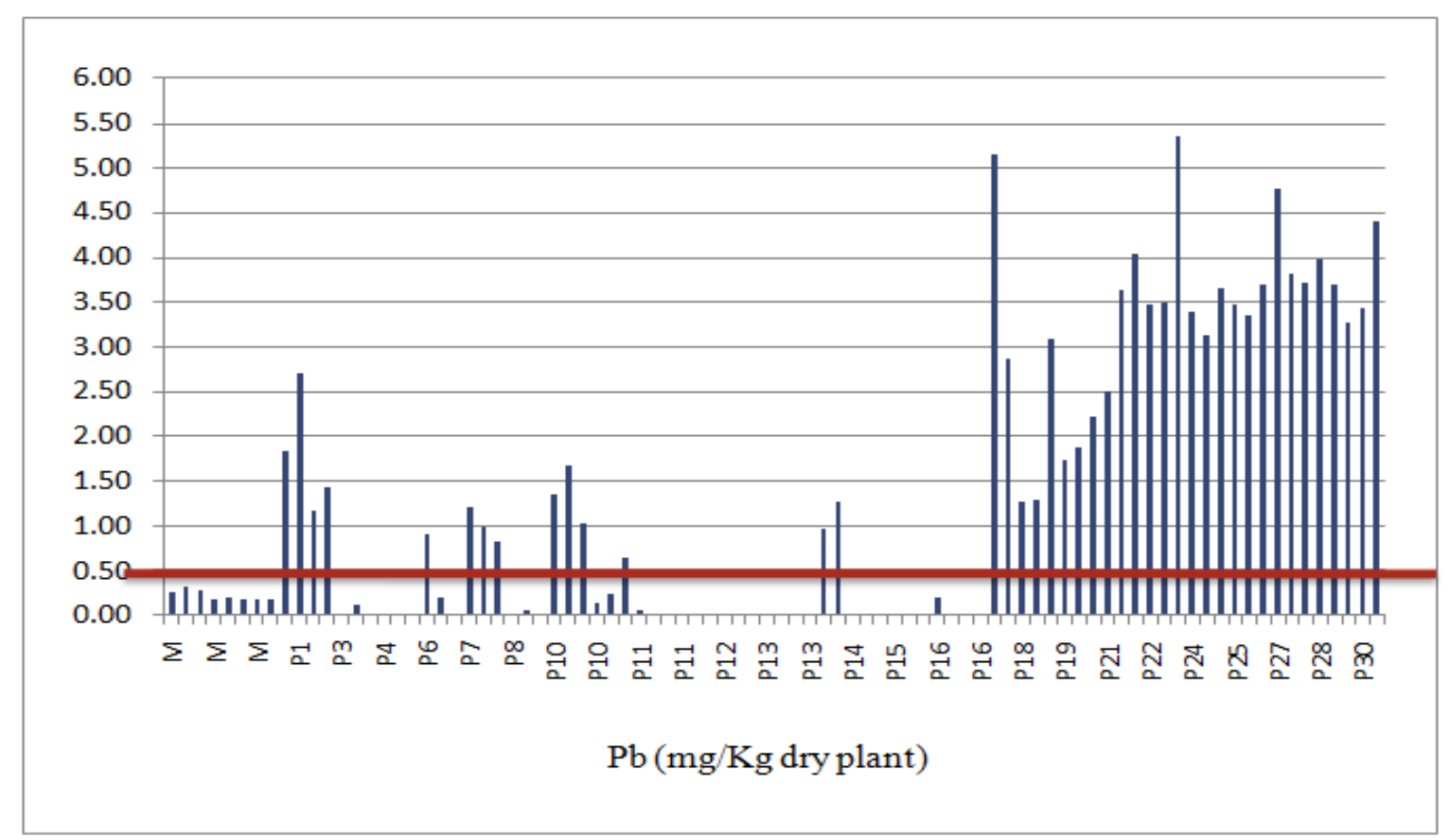

Figure 6. Graphical representation of $\mathrm{Pb}$ concentrations recorded for the studied plants.

The exceeding values for $\mathrm{Cd}$ and $\mathrm{Pb}$ were recorded in the identified area (P1-P9) and in the group of locations P16-P30. The increased concentrations of heavy metals in the plants harvested in the identified area can be explained by the fact that soil acidity promotes their bioavailability.

The analysis of the species showed that Trifolium pratense (Red clover), Plantago lanceolata (Ribwort plantain), Achillea millefolium (Yarrow) recorded the most exceeding values of the allowed normal value.

The values measured for the $\mathrm{Cd}$ concentration of the Trifolium pratense varied between 0.2225 and $1.1874 \mathrm{mg} / \mathrm{Kg}$, and between 0.9995 and $4.7782 \mathrm{mg} / \mathrm{Kg}$ for the $\mathrm{Pb}$ concentration.

For Plantago lanceolata, the values measured for the $\mathrm{Cd}$ concentration varied between 0.3135 and 0.8247 $\mathrm{mg} / \mathrm{Kg}$, and between 1.0287 and $4.4168 \mathrm{mg} / \mathrm{Kg}$ for the $\mathrm{Pb}$ concentration. G SZAREK-ŁUKASZEWSKA \& al [26] examined above-ground parts of $P$. Lanceolata. and measured values up to $65.6 \mathrm{mg} / \mathrm{Kg} \mathrm{Cd}, 157 \mathrm{mg} / \mathrm{Kg} \mathrm{Pb}$. I DIMITROVA \& al [27] concluded that $P$. Lanceolata can be used as bio accumulative indicators for $\mathrm{Zn}, \mathrm{Pb}$ and $\mathrm{Cd}$.

For Achillea millefolium values measured for the $\mathrm{Cd}$ concentration varied between 0.3755 and $0.9175 \mathrm{mg} / \mathrm{Kg}$ and between 1.3003 and $3.8375 \mathrm{mg} / \mathrm{Kg}$ for the $\mathrm{Pb}$ concentration.

To identify the correlation between the increased concentrations from plants and soil, the maximum concentrations of the two heavy metals recorded for the spontaneous flora taken from each location and exceeding the maximum allowed value were represented and overlapped on the concentrations distribution map (Fig. 3 and Fig. 4). Overlapping the spatial distributions of soil concentrations and the values that exceeded the normal concentration range for plant material did not lead to the conclusion that there was a relationship between the identified maximum and minimum levels.

The high values for $\mathrm{Cd}$ and $\mathrm{Pb}$ recorded for the spontaneous vegetation raised questions about the quality of the grazing area and the possibility for transfer to humans.

\section{Conclusions}

The analysis of laboratory data revealed that soil pollution was caused by the anthropogenic activity in the oil extraction process, all values recorded in the process for total petroleum hydrocarbons presenting exceeding values of the intervention threshold. Increased concentrations of heavy metals for the investigated area confirm that the entire zone is affected by the residual pollution with TPH. This conclusion was supported by the exceeding values of the threshold levels recorded for the control sample, $\mathrm{Cd}$ and $\mathrm{Pb}$ exceeding even the alert threshold.

Both $\mathrm{Cd}$ and $\mathrm{Pb}$ exceeded the normal values for the spontaneous flora in most locations, thus the contamination of the plants in the grazing areas with these heavy metals was established.

The selected area was appreciated as a risk area necessitating intervention for depollution.

The use of correlation between the distribution maps proved a useful tool to identify the pollution sources and for understanding the pollutants' migration, but also to identify external intervention on the soil. 


\section{References}

1. D.A. MUSTAFA, H. JUAHIR, K. YUNUS, A.M. AMRAN, C. HASNAM, C. NORAINI, F. AZAMAN, Z.I. ABIDIN, H.S AZMEE, H.N. SULAIMAN. Oil spill related heavy metal: a review. MJAS, 19:6 (2015).

2. A.M. MICHAEL, T.P. OJHA, Principles of agricultural engineering. Eds., Jain Brothers, inc., New Delhi, 2006.

3. L. PÂRVAN, I. ANTON, C. SÎRBU, T. CIOROIANU, M. DUMITRU, M. MUȘAT. The effect of Bioremediation Technologies on Mobile Potassium Content from Polluted Soil with Crude oil. Rom. Biotech. Lett, 21:4 (2016).

4. B.M. MCBRIDE. Environmental Chemistry of Soils. Eds., OUP., inc., New York, 1994.

5. I.O. ASIA, S. I. JEGEDE, D.A. JEGEDE, O.K. IZEIYAMU, E.B. AKPASUBI. The effects of petroleum exploration and production operations on the heavy metals contents of soil and groundwater in the Niger Delta. Int. J. Phys. Sci, 2:10 (2007).

6. J.G. LÜ, R.J. XU, Q.H. ZHANG, J.Y. LIU, C.Y. LIAO, F.S. WEI. Primary investigation of the pollution status of polycyclic aromatic hydrocarbons (PAHs) in water and soil of Xuanwei and Fuyuan, Yunnan Province, China. Chinese Sci. Bull, 54:19 (2009).

7. S.J. ROBERTSON, W.B. MCGILL, H.B. MASSICOTTE, P.M RUTHERFORD. Petroleum hydrocarbon contamination in boreal forest soils: A mycorrhizal ecosystems perspective. Biol. rev, 82:2 (2007).

8. A. SINGH, S. EAPEN, M.H. FULEKAR. Potential of Medicago sativa for uptake of cadmium from contaminated environment. Rom. Biotech. Lett, 14:1 (2009).

9. STANDARDS ASSOCIATION FROM ROMANIA, ASRO, STAS 7184/1-75 Soil sampling for soil and agrochemical soil studies, 2002 (in Romanian).

10. INTERNATIONAL ORGANIZATION FOR STANDARDIZATION, ISO, ISO 11464/1994 Soil Quality - Pretreatment of samples for physicochemical analysis, Geneva, Switzerland, 1994.

11. STANDARDS ASSOCIATION FROM ROMANIA, ASRO, ISO 950/1999 Vegetable sampling, 1999 (in Romanian).

12. STANDARDS ASSOCIATION FROM ROMANIA, ASRO, ISO 1839/1980, updated in 2013 - Vegetable sampling, 2013 (in Romanian).

13. INTERNATIONAL ORGANIZATION FOR STANDARDIZATION, ISO, ISO 10390/2005, Soil Quality - Determination of $\mathrm{pH}$, Switzerland, Geneva, 2005.

14. WTW, WTW pHotoFlex/pHotoFlexTurb Photometry Analysis Manual, Weilheim, Germany: WTW GmbH, 2009.

15. UNIVERSIDA DE VIGO, Laboratorio Grupo de Bioprocesos, D.d.I.Q., Edificio Isaac Newton, Protocolos caracterizacion suelos, Vigo, Spania, 2012.
16. INTERNATIONAL ORGANIZATION FOR STANDARDIZATION, ISO, ISO 11047 Soil Quality Determination of cadmium, chromium, cobalt, copper, lead, manganese nickel and zinc. Flame and electrothermal atomic absorption spectrometric methods. Geneva, Switzerland, 1998.

17. VARIAN. Varian AA 240FS Analysis Manual, Published by Varian Inc., 2007.

18. ROMANIAN GOVERNMENT. Order no. 756/ 3.11.1997 to approve legislation on environmental pollution assessment, Official Gazette no. 303 bis / November 6 ${ }^{\text {th }}$, Published by G. Document, 1997 (in Romanian).

19. ROMANIAN GOVERNMENT. Order no.640 of 19 September 2001 on the conditions of safety and quality for fresh vegetables and fruits intended for human consumption, published in the Official Gazette no. 173 of March 13, 2002. Published by Ministry of Agriculture, 2001 (in Romanian).

20. L. RUSĂI, M.E. FÂCIU, G. GĂMAN, I. ȘTEFĂNESCU. Spatial variation of phisyco-chemical parameters of soils from a historic contaminated site with oil products. 11 th International Conference on Environmental Legislation, Safety Engineering and Disaster Management ELSEDIMA, Building Disaster Resilience in a Changing World, Cluj, 2016, p. 168.

21. A. FIELD. Discovering statistics using SPSS, eds., SAGE Publications, 2006.

22. A.F. POTRA, V.MICLE, I.M SUR, C.S. BĂBUT,. Soil quality evaluation in Carbochim Cluj-Napoca area in order to remediate (in Romanian). Analele UCB, 3 (2011).

23. L. RUSAI (FERENȚ), M.E. FACIU, G. GAMAN, I. STEFĂNESCU, I.M. LAZĂR. Estimation of historic pollution sources from an oil extraction affected site. U.P.B. Sci. Bull., Series B, 81:2 (2019).

24. I.M. BERAR, V. MICLE, V. OROS, C.S. COCIORHAN, A.M. URS. Studies and research on soil quality assessment in S.C. Romplumb SA. Baia Mare in order to remedy the polluted lands. ProEnv, 3 (2010) (in Romanian).

25. C.S. BĂBUț, V. MICLE, A.F. POTRA, A. COSTE. Analysis of heavy metals from a polluted site in order to rehabilitate it. A case study on the Zlatna area. ProEnv, 6 (2013).

26. G. SZAREK-LUKASZEWSKA, M. NIKLIŃSKA. Concentration of alkaline and heavy metals in Biscutella laevigata L. and Plantago lanceolata L. growing on calamine spoils (S. Poland). Acta Biol Cracov Bot, 44 (2002)

27. I. DIMITROVA, L. YURUKOVA. Bioindication of anthropogenic pollution with Plantago lanceolata (Plantaginaceae): metal accumulation, morphological and stomatal leaf characteristics. Phytol Balcan, 11 (2005). 